\title{
WP 21_14
}

\author{
Michael Ellington \\ University of Liverpool Management School, UK
}

\author{
Costas Milas
}

University of Liverpool Management School, UK

The Rimini Centre for Economic Analysis, Italy

\section{GLOBAL LIQUIDITY, MONEY GROWTH AND UK INFLATION}

Copyright belongs to the author. Small sections of the text, not exceeding three paragraphs, can be used provided proper acknowledgement is given.

The Rimini Centre for Economic Analysis (RCEA) was established in March 2007. RCEA is a private, nonprofit organization dedicated to independent research in Applied and Theoretical Economics and related fields. RCEA organizes seminars and workshops, sponsors a general interest journal The Review of Economic Analysis, and organizes a biennial conference: The Rimini Conference in Economics and Finance (RCEF) . The RCEA has a Canadian branch: The Rimini Centre for Economic Analysis in Canada (RCEACanada). Scientific work contributed by the RCEA Scholars is published in the RCEA Working Papers and Professional Report series.

The views expressed in this paper are those of the authors. No responsibility for them should be attributed to the Rimini Centre for Economic Analysis. 


\title{
Global liquidity, money growth and UK inflation
}

\author{
Michael Ellington ${ }^{*}$ and Costas Milas ${ }^{*}$
}

\begin{abstract}
This paper examines the inflationary impact of domestic and global liquidity conditions on UK inflation through the lens of monetary aggregates. To do so, we rely on standard linear models as well as non-linear models that allow for regime switching behaviour in terms of a contained regime (when domestic money growth is relatively concealed) versus an uncontained regime (when domestic money growth is unusually unconcealed). We find that global liquidity yields inflationary pressures in the UK over and above the impact of domestic money growth, spare capacity and money disequilibria (the latter accounting for the property sector and financial asset markets). All effects are regime-switching as they depend on whether domestic money growth is contained within or exceeds threshold boundaries. Finally, broad (M4) money has greater explanatory power than divisia money in modelling UK inflation.
\end{abstract}

JEL Codes: C5, E5

Keywords: Global liquidity; inflation; divisia money; M4; non-linear model

*University of Liverpool Management School, Chatham Street, L69 7ZH, Liverpool, UK

*Corresponding Authors: E-mail addresses: m.t.ellington@liverpool.ac.uk (M. Ellington), costas.milas@liverpool.ac.uk (C. Milas). 


\section{Introduction}

The recent global financial crisis witnessed a detrimental shock to liquidity and credit conditions followed by a somewhat staggered recovery. In response to the financial turmoil, monetary policy-makers in major economies pursued an unprecedented path of interest rate cuts and repeated rounds of asset purchase facilities involving predominantly the purchase of long-term government bonds and other related assets (more commonly known as quantitative easing, QE). Preconditions for this global phenomenon, as observed by Goodhart and Hoffman (2008), consisted simultaneously of inflated asset prices, house price persistence, surging money growth rates and low capital market yields; implying that asset markets were awash with liquidity. The UK's experience of the financial disquietude comprised of a double-dip recession followed by a fragile recovery.

The UK's response to the financial crisis saw the government attempt to stimulate the property sector through schemes such as 'help to buy' (HTB) which provides equity loans of up to $20 \%$ of a property's value (on properties up to the value of $£ 600,000$ ) given the buyer has $5 \%$ of the value of the property as a deposit (with the remaining $75 \%$ requiring a mortgage). This is consistent with the view-alluded to by Mark Carney (the Governor of the Bank of England (BoE)) in the June 2014 Financial Stability Report press conference-that historically recessions preceded by a property bust have historically been more severe than those without. The UK housing market is thought to affect the economy through three channels: domestic demand (documented in the BoE's November 2013 Inflation Report as having prospects for medium term inflationary pressure); financial stability and debt levels and resource allocation.

In parallel with this, the UK's monetary policy response consisted of successive interest rate cuts which froze at $0.5 \%$ on March $5^{\text {th }} 2009$ and have remained there since; along with three rounds of QE from March 2009-July 2012 summing to $£ 375 \mathrm{bn}$. QE is thought to work via three main channels: the macro-policy/news channel; the signalling channel and the portfolio rebalancing channel (for a critical analysis see e.g. Martin and Milas (2012)). However, during the first round of QE, M4 growth (the usual monetary aggregate monitored by the Monetary Policy Committee) did not pick up. However divisia money did, thus raising the question as to what measure of money matters for inflation. Divisia money assigns weights to the component assets of M4 in accordance to their 'liquidness' such that those bearing higher interest payments (thought to be less useful for transaction purposes) are allocated a lower 
weight. With this in mind, Darrat et al. (2005) and Hancock (2005) argued that compared with M4, divisia money has a closer relationship to expenditure ${ }^{1}$.

In this paper not only do we aim to address the aforementioned; we look to explore an additional channel through the lens of broad and divisia global money aggregates. This is based on the premise that economies are largely open to fluctuations in international capital flows and more integrated financial markets. There are various reasons as to why global liquidity might yield inflationary pressures for the UK. First, global aggregates are thought as likely to embody cross-country movements in money aggregates (as a result of capital flows between different regions). This may make the link between inflation, money and output difficult to disseminate and therefore potentially deemed redundant (Sousa and Zaghini (2006)). Additionally, Belke et al. (2010) argue that domestic money aggregates/national liquidity have become more difficult to interpret due to the vast increase in volume of international capital flows. This is echoed in Giese and Tuxen (2007) as the integration of today's financial markets and fluctuations in the money supply of one country have the possibility to be absorbed by demand elsewhere. Perhaps more importantly, contemporaneous shifts in the money supply of major economies could result in spill-over effects into domestic rates of inflation. It is well established that global liquidity has implications with consumer and asset prices on a global scale (see e.g. Baks and Kramer (1999), Ciccarelli and Mojon (2010), Sousa and Zaghini (2008), Rueffer and Stracca (2006) and Belke et al, (2010, 2014)). Ample movements in global liquidity have also received attention from authors in the context of financial crisis (see e.g. Goldstein (1998)-in relation to the Asian crisis-and Borio and Filardo (2007) for the more recent global financial crisis). However, there seems to be very little documentation on the effects that global liquidity has for a single nation's economy, its implications for policy making purposes or relationship(s) during times of financial crisis.

The main contribution of this paper lies in two main areas: first, we look to quantify and compare the relationship between two measures of UK inflation, M4 growth and divisia money from 1983Q4-2014Q1 and 1989Q2-2014Q1 for Retail Price Index (RPI) inflation and Consumer Price Index (CPI) inflation, respectively. UK divisia money aggregates are advocated by Florackis et al. (2014) as holding greater explanatory and forecasting power for real GDP growth than the UK's broad money aggregate (M4). Second, we formally construct

\footnotetext{
${ }^{1}$ There are various theoretical motivations for the use of divisia aggregates in money aggregation theory advocating their attractiveness; see e.g. Belongia (1996), Lucas (2000), Stracca (2004) and Drake and Mills (2005).
} 
global broad money and global divisia money aggregates as proxies for global liquidity. The inflationary impact of these measures on UK inflation is then explored after taking into account additional variables such as the output gap (see e.g. Clements and Sensier (2003), Osborn and Sensier (2009) and Milas (2009)) and a money disequilibrium measure (see e.g. Milas (2009)) which also accounts for the property sector and financial asset markets. We show the property sector and financial assets exhibit wealth effects, which is confluent with recent government policy and the empirical literature (for the Euro area see e.g. Setzer and Greiber (2007), Boone and Van den Noord (2008), Beyer (2009), Sousa (2010), Dreger and Wolters (2010, 2014) and De Santis et al. (2013)).

In constructing our global measures, we follow the methods outlined in Sousa and Zaghini (2006) and D'Agostino and Surico (2009) to proxy global liquidity. Following the recommendations in the aforementioned, we assign a time-varying rank upon the influence each nation attributes to global liquidity relative to its share in an aggregated GDP series (thus, economies with a larger share in an aggregated GDP series are assigned a higher weight within the global liquidity aggregate).

We look to build upon the existing strand of literature exploring UK inflation dynamics (see e.g. Hendy (2001), Clements and Sensier (2003), Osborn and Sensier (2009) and Milas (2009)) by employing both linear and non-linear models. We also re-visit the debate on whether M4 money movements really matter for UK policy-making ${ }^{2}$. However, our study differs in that we also focus on liquidity conditions from both a domestic and international perspective.

Our results are summarised as follows: First, we find evidence that global liquidity yields inflationary pressures in the UK over and above the impact of domestic money growth, spare capacity (the output gap) and money disequilibria (the latter accounting for the property sector and financial asset markets). Second, all effects are regime-switching as they depend on whether domestic money growth is contained within or exceeds threshold boundaries. More specifically, CPI inflation is mainly driven by spare capacity considerations and global liquidity effects when M4 growth is contained within regime boundaries. On the other hand, domestic liquidity effects (domestic M4 growth and M4 disequilibria) dictate inflation movements when M4 growth is either too high or too low. Third, we find no evidence in favour of divisia money (over M4 money) in modelling UK inflation. From a policy

\footnotetext{
${ }^{2}$ For commentary on this debate, see Milas (2009).
} 
perspective, we note the obvious: although the Bank of England's MPC cannot target global liquidity, it should monitor closely domestic money growth as the inflationary effects of both domestic money and global liquidity depend on money growth boundaries.

The rest of this paper is organised as follows. Section 2 outlines constructions of the money disequilibrium and global liquidity. Section 3 gives a description of the data and a discussion of the linear and non-linear models used. Section 4 reports our empirical findings. Finally, section 5 provides a summary, discusses policy implications and outlines potential avenues for future research.

\section{Data description, money disequilibria and global liquidity}

\subsection{Data description}

UK quarterly data on M4, money divisia, the 10-year government bond, the 5-year government bond and the 3-month Treasury bill rate are available from the BoE database. The RPI and CPI series are available from the Office for National Statistics (ONS), as is GDP data. FTSE All-Share prices, house prices and the house price-earnings ratio are available from Thomson Reuters Datastream. Monetary aggregates and GDP data for the constructions of global liquidity are from the Organisation for Economic Co-operation and Development (OECD) and the Centre for Financial Stability (CFS). The output gap is constructed as the proportional difference between GDP and the average of two alternative measures of equilibrium output: the Hodrick and Prescott (1997) trend and a simple quadratic trend ${ }^{3}$. Figures 1-2 plot the data.

\subsection{Money disequilibria}

In relation to the implementation of recent government policy, it seems necessary to assume that housing variables within a long-run money demand framework should exhibit wealth effects. This expectation, that the housing sector should be positively related to real money

\footnotetext{
${ }^{3}$ The Hodrick and Prescott (1997) approximation of the output gap was thought to under-estimate the amount of spare capacity and the quadratic trend estimate was deemed as an over-estimate; see also Ahmad et al. (2014). We also considered the Office for Budget Responsibility's output gap estimate in earlier analysis; models using this output gap produced parameter estimates similar to those reported here, yet they resulted in inferior statistical fit.
} 
balances, rests on the discussion related to HTB in section 1 and the notion that the $40 \%$ fall in private sector housing investment of 2008-2009 attributed to a quarter of the fall in GDP (noted in the Bank of England November 2013 Inflation Report). Since there is no theoretical prior as to how housing variables or financial assets should enter the system, the issue must be left to empirical investigation ${ }^{4}$.

The money disequilibrium constructions are the residuals (multiplied by 100) from the Engle and Granger (1987) long-run regressions given by ${ }^{5}$ :

$\operatorname{diseq}_{t}^{r p i, M 4}=\left(m 4-p^{r p i}\right)_{t}+11.30-1.40 y_{t}-0.05\left(i_{10 y r}-i_{5 y r}\right)_{t}-0.12 h_{t}-0.13 f_{t}$,

diseq $_{t}^{r p i, d m}=\left(d m-p^{r p i}\right)_{t}+11.72-0.81 y_{t}-0.07\left(i_{10 y r}-i_{5 y r}\right)_{t}-0.33 h_{t}-0.05 f_{t}$,

$\operatorname{diseq}_{t}^{c p i, M 4}=\left(m 4-p^{c p i}\right)_{t}+12.81-1.72 y_{t}-0.01\left(i_{10 y r}-i_{3 m t h}\right)_{t}-0.13 h(p / e)_{t}$,

$\operatorname{diseq}_{t}^{c p i, d m}=\left(d m-p^{c p i}\right)_{t}+14.50-1.28 y_{t}-0.01\left(i_{10 y r}-i_{3 m t h}\right)_{t}-0.40 h(p / e)_{t}$.

where $\operatorname{diseq}_{t}^{x, y}$ is the money disequilibrium construction, the $x$ superscript denotes the price index used and the $y$ superscript denotes the money aggregate used in each specification; $\left(m 4-p^{x}\right)_{t},\left(d m-p^{x}\right)_{t}$ denote the log level of real M4 and real divisia

\footnotetext{
${ }^{4}$ Variables entering the specification with a negative sign are thought to exhibit substitutive properties.

5 All variables within these systems were confirmed to be unit root processes. To save space, we refrain from reporting the test results (these are available on request).
} 
money balances where the $x$ superscript denotes the price index used as a proxy for prices; $y_{t}$ is the log level of real GDP; $i_{10 y r}$ is the 10 -year government bond rate; $i_{5 y r}$ is the 5 -year government bond rate and $i_{3 m t h}$ is the 3-month Treasury bill rate. The interest rate differential used in specifications (1)-(4) is therefore the slope of the respective term structures. The variable $h_{t}$ is the log level of real standardised average UK house prices (scaled by the appropriate price index for each specification); $f_{t}$ is the log level of real stock prices proxied by the FTSE All-Share index (scaled by the appropriate price index for each specification) and $h(p / e)_{t}$ is the log level of the UK house price-earnings ratio (calculated as the average standardised house price scaled by the average earnings of a full-time male UK employee).

As evident in (1)-(4), all variables enter with either the correct theoretical or anticipated sign based on the aforementioned discussions regarding housing variables and asset prices specific to the UK economy. Similarly, the magnitude of each variable is also consistent with existing empirical applications. The wealth effects of the housing variables conform to those reported for the Euro area (see e.g. Setzer and Greiber (2007), Dreger and Wolters (2010) and De Santis et al. (2013)). Asset prices in the above specifications are also shown to exert a positive effect on the demand for real balances; implying complementarity.

Table 1 reports three stationarity tests that explore the stationarity properties of the disequilibrium constructions. The tests reported are: the EGS test (Elliot et al (1996)); the KPSS test (see Kwiatkowski et al (1992)) and the ERS test (see Elliot et al (1996)). The former and the latter test the null hypothesis of a unit root, whereas KPSS tests the null hypothesis of stationarity ${ }^{6}$. As can be seen from Table 1 , tests results in columns $2-4$ confirm that the money disequilibria are stationary. However, there appears some ambiguity in column 1 where only around half of the test statistics confirm marginal stationarity of the money disequilibrium (using RPI and M4 in construction). As a form of robustness analysis, we turned to the Johansen $(1988,1995)$ methodology. All Vector Autoregressive (VAR) estimates support evidence of cointegration with at least one of the tests (either Johansen's $\lambda$ -

\footnotetext{
${ }^{6}$ For (1), Augmented Dickey Fuller (ADF) test statistics are: $\operatorname{ADF}(0$ lag $)=-2.25, \operatorname{ADF}(1$ lag $)=-2.67, \operatorname{ADF}(2$ lags $)=-2.66$. For (2), Augmented Dickey Fuller (ADF) test statistics are: $\mathrm{ADF}(0 \mathrm{lag})=-2.68, \mathrm{ADF}(1 \mathrm{lag})=-2.62$, $\operatorname{ADF}(2$ lags $)=-2.87$. For (3), Augmented Dickey Fuller (ADF) test statistics are: ADF(0 lag) $=-2.11, \operatorname{ADF}(1$ lag $)=-2.83, \mathrm{ADF}(2$ lags $)=-2.84$. For (4), Augmented Dickey Fuller (ADF) test statistics are: $\mathrm{ADF}(0$ lag $)=-1.45$, $\mathrm{ADF}(1 \mathrm{lag})=-1.64, \mathrm{ADF}(2 \mathrm{lags})=-2.05$. The MacKinnon (1991) $5 \%$ critical value for (1) $-(2)$ is -4.53 and for (3)-(4) is -4.20 , ADF tests were unable to reject the null hypothesis in these cases; we return to this issue below when reporting our non-linear model estimates.
} 
trace or $\lambda$-max test) in favour of one cointegrating vector (to save space, we do not report these results but are available on request) ${ }^{7}$.

Figures 3 and 4 plot the money disequilibrium constructions as in (1)-(4). Plots in both Figures show that mean crossings are relatively frequent with substantially more variability in the money disequilibria using real M4 balances. Positive deviations from the long-term equilibrium suggest excess liquidity within the economy possibly indicating that housing and other asset prices are inflated along with the risk of inflationary pressures. On the other hand, negative deviations from the long-run equilibrium imply there is (too) little liquidity in the economy possibly linked to a period of disinflation. Notice (from Figures 3 and 4) that, towards the end of the sample, there is considerable divergence between M4 money disequilibria and divisia money disequilibria. In the former case, liquidity has reverted towards equilibrium (or is now moving below equilibrium). In the latter case, however, liquidity appears to be above equilibrium. These differences arise because divisia money may be thought of as holding informational content regarding liquidity conditions/perceptions in the UK that M4 does not capture. This is likely to stem from the weighting component in divisia money; arguably, these disequilibria constructions may be better capturing QE effects through the portfolio re-balancing channel (this could be driven by divisia money having a closer relationship with aggregate spending as empirically noted by Florackis et al. (2014).

\subsection{Global liquidity}

Next, we turn our attention to measures of global liquidity. More formally, the levels of broad and divisia global liquidity are given by:

$G L_{t}^{\text {broad }}=\sum_{i=1}^{4} \omega_{i, t} m_{i, t}$,

where $\omega_{i, t}=G D P_{i, t} / G D P_{t}^{a g g}$, and

$G L_{t}^{d i v}=d m_{U S, t}$.

\footnotetext{
${ }^{7}$ For VAR estimates using log levels of divisia money, cointegration was conditional on the inclusion of trend into the cointegrating vector.
} 
In (5) $m_{i, t}$ represents the level of country $i$ 's money aggregate converted at PPP exchange rates ( $i=$ Canada, US, Japan and the Euro area; we use the term "country" in a loose manner for the Euro area). This is then weighted by $\omega_{i, t}$ which is country $i$ 's share in an aggregated GDP series, $G D P_{t}^{a g g}$ (i.e. $G D P_{i, t} / G D P_{t}^{a g g}$ ). Similarly in (6), global divisia is approximated by US divisia money, $d m_{U S, t}$, converted at PPP exchange rates. Figure 5 plots the annual growth in broad and divisia money global liquidity. We observe a sharp decline in liquidity on a global scale at the time of the recent financial crisis. Notice also that the liquidity shock for global divisia is more severe than that for global broad money possibly explained by the differential weighting applied to the series (for global broad money we rely on four countries whereas for global divisia we rely solely on the US). For both proxies, there is a surge post2009 back into positive growth rates suggesting these variables are picking up rounds of QE effects. Again, the surge is greater when looking at global divisia indicating a quicker response of this aggregate to expansionary monetary policies ${ }^{8}$.

\section{Linear and non-linear models}

Our analysis starts with a linear model of the form:

$\pi_{t}^{x}=\beta_{0}+\beta_{i}^{\prime} X_{t-l}+v_{t}$

where $\pi_{t}^{x}$ is the annual rate of inflation, the $x$ superscript denotes the price index the rate of inflation derives from; $X_{t-l}$ is a vector of control variables, namely lagged inflation $(\pi)$, M4 growth (M4), divisia money growth $(D M)$, global liquidity growth $\left(G L^{\text {broad }}, G L^{\text {divisia }}\right)$-or the rate of change (acceleration) of global liquidity growth, output gap (gap) (or the rate of change in the output gap) and money disequilibrium (diseq $)^{9} . \beta_{i}^{\prime}$ denotes the coefficient associated to the respective control variable $\left(i=\pi, M 4, D M, G L^{\text {broad }}, G L^{\text {divisia }}\right.$, gap, diseq $)$, and $v$ is an error term ${ }^{10}$.

\footnotetext{
${ }^{8}$ However, the rapid response of global divisia might also rest on the fact that the proxy utilises only the US divisia aggregate for which we have data. This might be picking the sizeable QE policies of the Fed. Indeed, in June 2014, the balance sheet of the Fed stood at $\$ 4.4$ trillion, five times its pre-crisis size.

${ }^{9}$ The rate of change in the output gap eradicates any measurement error in the approximation and may be yielded as more favourable than the raw output gap estimate (see e.g. Walsh (2003)); our models of RPI inflation favoured the output gap's first difference. For proxies of global liquidity, the acceleration rate of global liquidity resulted in a preferable statistical fit for models using the CPI measure of inflation.

${ }^{10}$ Regressors do not explicitly share a common lag length. We include lagged values of all variables up to lag 4; empirical specifications are given in Table 2. Model selection criteria were based on the empirical models that yielded the best statistical fit in terms of the regression standard error and the Akaike Information Criterion (AIC).
} 
Previous studies regarding UK inflation dynamics provide substantial evidence that the relationship might be non-linear (see e.g. Arghyrou et al (2005); Osborn and Sensier (2009) and Milas (2009)). Thus, baseline specifications are then subject to a battery of diagnostics testing whether the model's parameters are time invariant (see Lin and Teräsvirta (1994)) or neglect any potential non-linearity (using tests for fourth order ARCH effects and bootstrapped $p$-values of the BDS (see Brock et al (1996)) independence test based upon varying correlation dimensions). Upon rejection of parameter constancy in favour of parameters that change smoothly throughout time, we consider non-linear models that allow for possible asymmetries relative to a given 'transition' variable. More formally, inflation is modelled as

$\pi_{t}^{x}=\beta_{0}+\left(\beta_{i, 1}^{\prime} X_{t-l}\right) \alpha_{t-l}^{\delta}+\left(\beta_{i, 2}^{\prime} X_{t-l}\right)\left(1-\alpha_{t-l}^{\delta}\right)+\eta_{t}$,

where

$\alpha_{t-l}^{\delta}=1-\left[\left(1+\exp \left\{-\gamma\left(\delta_{t-l}-\tau\right) / \sigma_{\delta_{t-l}}\right\}\right)\right]^{-1}$

or

$\alpha_{t-l}^{\delta}=1-\left[\left(1+\exp \left\{-\gamma\left(\delta_{t-l}-\tau_{1}\right)\left(\delta_{t-l}-\tau_{2}\right) / \sigma_{\delta_{t-l}}^{2}\right\}\right)\right]^{-1}$.

Equation (8) states that inflation is modelled as a weighted average of two linear models ${ }^{11}$. $X_{t-l}$ are the regressors from the linear specification in (7), $\delta_{t-l}$ is the transition variable and $\eta$ is an error term. $\alpha_{t-l}^{\delta}$, as defined in (9), is the logistic transition function and $\alpha_{t-l}^{\delta}$, as defined in (10), is the quadratic logistic transition function as discussed in van Dijk et al. (2002). According to (8) and (9), inflation exhibits regime-switching behaviour depending on whether $\delta_{t-l}$ is below or above an endogenously determined threshold $(\tau)$ given by the regime weights $\alpha_{t-l}^{\delta}$ and $\left(1-\alpha_{t-l}^{\delta}\right)$, respectively. When $\delta_{t-l}$ is below $\tau, \alpha_{t-l}^{\delta} \rightarrow 1$ and the

\footnotetext{
${ }^{11}$ Our non-linear models imposed a common intercept; doing so facilitated convergence of all model estimates. Table 3 reports parsimonious non-linear models that include $X_{t-l}$ regressors with $t$-ratios higher than 1 .
} 
inflationary impact is given by $\beta_{i, 1}^{\prime}$. Contrastingly, when $\delta_{t-l}$ is above $\tau, \alpha_{t-l}^{\delta} \rightarrow 0$ and the inflationary impact is given by $\beta_{i, 2}^{\prime}$. According to (8) and (10), inflation exhibits regimeswitching behaviour adjustment depending on whether $\delta_{t-l}$ is between or outside of two endogenously determined regime boundaries $\tau_{1}, \tau_{2}\left(\tau_{1}<\tau_{2}\right)$; with regime weights given by $\alpha_{t-l}^{\delta}$ and $\left(1-\alpha_{t-l}^{\delta}\right)$, respectively. When $\delta_{t-l}$ is between $\tau_{1}$ and $\tau_{2}, \alpha_{t-l}^{\delta} \rightarrow 1$ and the inflationary impact is given by $\beta_{i, 1}^{\prime}$. When $\delta_{t-l}$ is outside of the regime boundaries, $\alpha_{t-l}^{\delta} \rightarrow 0$ and inflation is given by $\beta_{i, 2}^{\prime}$. The parameter $\gamma(\gamma>0)$ determines how rapid the transition is from one regime to another and is made scale-free by dividing it by the standard deviation of $\delta_{t-l}$ for (9) and the variance of $\delta_{t-l}$ for (10), respectively (see Granger and Teräsvirta, 1993).

These types of models allow us to assess the impact of domestic and global money movements during an illiquid regime versus a liquid regime when using the transition function as in (9). On the other hand, (10) allows us to assess the inflationary impact of liquidity conditions during a 'contained regime' (when liquidity is concealed between two boundaries) and an 'uncontained regime' (when liquidity exceeds the realms of the respective boundaries). Since the focus of this study is on the link between UK inflation and liquidity conditions, we consider regime-switching behaviour with respect to liquidity variables (that is, M4 money growth, divisia money growth, the money disequilibria constructions and both proxies for global liquidity) ${ }^{12}$.

\section{Empirical evidence}

\subsection{Empirical results}

Our empirical specifications for different versions of the linear model in (7) are reported in Table 2. We report four versions of the linear model; two models of RPI inflation and two models of CPI inflation using combinations of M4 growth, divisia money growth, the output gap, global liquidity and the money disequilibrium. In all models reported, inflation is highly persistent (measured by the coefficient on lagged inflation which might proxy forwardlooking expectations; see e.g. Blanchard (1988)). Models of RPI inflation, reported in

\footnotetext{
${ }^{12}$ We also considered lagged inflation as a possible transition variable candidate. We abstain from reporting results of these non-linear models simply because our models with liquidity transition variables (a) exhibit a better statistical fit in terms of parameter constancy and (b) have important economic meaning for policymaking purposes. We omitted the output gap as a possible candidate as there is already evidence within the literature that inflation does not adjust asymmetrically to movements in the output gap (see Clements and Sensier (2003)).
} 
columns i) and ii), show that divisia money growth is statistically significant and has a more prominent inflationary impact than M4 growth. Columns iii) and iv) show instead that M4 seems to exert a stronger and more significant impact on CPI inflation than divisia money growth.

The impact of the rate of change in the output gap is strong and highly significant for models of RPI inflation. For CPI inflation, instead, output gap is found to exert a positive impact; however, this is statistically weak. In all models, money disequilibria have a positive (inflationary) but nevertheless, statistically insignificant effect; we return to this issue below as we find (for some non-linear models) cointegration effects when money growth drops outside a range of thresholds. Only for CPI inflation model iv), global liquidity, proxied by the rate of change in divisia growth, exerts a statistically significant impact.

All linear models fail the test for AR and ARCH effects ${ }^{13}$. Bootstrapped $p$-values from the BDS tests report no evidence of independence (with the exception of model iv) $)^{14}$. There is also substantial evidence that parameters of each respective model vary throughout time. The only exception is model ii) where test results imply parameters are time-invariant ${ }^{15}$.

Having rejected parameter constancy, we proceed by estimating non-linear specifications of the inflation models discussed in Table 2. To save space, we do not report the tests for the appropriate lag length of transition variable candidates or functional form of the logistic function (see van Dijk et al (2002) for details) ${ }^{16}$. Results from the sequential testing of potential transition variable candidates and functional form of the logistic function implemented indicated a variety of results. The non-linear models reported in Table 3 use a quadratic logistic function for models of RPI inflation and M4 money growth, CPI inflation and M4 money growth, and CPI inflation and divisia money growth. Each specification uses the respective domestic money growth rate as a transition variable. For the model of RPI inflation and divisia money growth, a logistic function, with money disequilibrium as a transition variable, is adopted instead ${ }^{17}$.

\footnotetext{
13 All $t$-ratios reported in Table 2 and Table 3 below are based on Newey-West Heteroskedasticity and Autocorrelation robust standard errors.

${ }^{14}$ These tests are implemented as an indication for any non-linearity neglected by the models (see e.g. Clements and Sensier (2003)).

${ }_{15}^{15}$ Given this model fails the AR, ARCH and BDS tests, we also proceed to test for regime-switching behaviour.

${ }^{16}$ Lagged transition variable candidates of up to and including 6 lags were considered.

17 The non-linear models reported in Table 3 provided the most favourable statistical fit. For these models, sequential tests do not favour potential transition candidates over one another. Notice also that we tried global
} 
We also report, in Table 3, additional diagnostics to assess the adequacy of the estimated non-linear models. First, we subject each of the non-linear models to an $F$-test; this tests the null hypothesis of no remaining non-linearity (based on the statistical significance of the cross product of the regressors in the non-linear model and the respective transition variable; see van Dijk et al. (2002) $)^{18}$. Second, we test the non-linear model against a linear model via an $F$-test (which tests $\beta_{i, 1}^{\prime}=\beta_{i, 2}^{\prime}$ such that there is no difference in the impact of regressors across regimes). Third, we report the ratio of standard deviation of the estimated residuals from the non-linear model and the linear model, $\widehat{\sigma_{N L}} / \widehat{\sigma_{L}}$. The lower the ratio, the better the fit of the non-linear model (conditional on the AIC of the non-linear model being preferred over that of the linear one).

Table 3 reports the non-linear estimates of the baseline specifications reported in Table 2. Columns i)-ii) report the non-linear models of RPI inflation using M4 growth and divisia money growth, respectively and columns iii)-iv) report the non-linear models of CPI inflation using M4 growth and divisia money growth, respectively ${ }^{19}$. First, consider specification i) in Table 3. This allows for regime-switching behaviour of RPI inflation relative to M4 growth being within or outside of the band of thresholds $\tau_{1}$, and $\tau_{2}$. These thresholds, which are statistically significant, are estimated at 2.82 and 9.54, respectively. The model indicates that when M4 growth is contained between $2.82 \%$ and $9.54 \%$, inflation is driven by past inflation and the rate of change in the output gap (with a statistically significant $t$-ratio of 3.15). Notice also that the output gap effects diminish sharply (as indicated by the $\gamma$ parameter estimate of 502) as we move from the contained regime to the uncontained regime ${ }^{20}$. In this uncontained regime, inflation is driven by lagged inflation, and money disequilibria (with a $t$-ratio of 5.36), whereas M4 growth and global liquidity exert statistically weak effects (their $t$-ratios are 1.51 and 1.55, respectively). As indicated in the second half of Table 3, specification i) passes the tests for parameter constancy, ARCH effects and no remaining non-linearity. Additionally, the model may not be simplified to a

liquidity (both broad money growth and divisia money growth) as potential transition candidates; these provided a poor statistical fit.

${ }^{18}$ Under the assumption of a common transition variable for all regimes.

${ }^{19}$ We found statistical evidence across all models (except specification iii) in Table 3 ), that inflation persistence was not regime dependent based on an $F$-test under the null hypothesis $H_{0}: \beta_{\pi, 1}^{\prime}=\beta_{\pi, 2}^{\prime}$.

${ }^{20}$ The $\gamma$ estimate suggests an instantaneous switch from one regime to the other. However, it is poorly determined. van Dijk et al. (2002) discuss the difficulty in getting accurate estimates of $\gamma$. The likelihood function is very insensitive to $\gamma$ and therefore, precise estimation of this parameter is not likely. 
linear model and has a lower than 1 (i.e. $\widehat{\sigma_{N L}} / \widehat{\sigma_{L}}=0.85$ ) residual standard deviation ratio; this appears more than sufficient for the AIC to select the non-linear model.

Next, consider specification ii) in Table 3. This models RPI inflation in terms of regimeswitching behaviour depending on whether the divisia money disequilibrium construction is above or below an endogenously determined threshold (the threshold estimate of $-0.52 \%$ is statistically insignificant). In terms of fit, this model is the same as-if not marginally inferior to-its linear counterpart since $\widehat{\sigma_{N L}} / \widehat{\sigma_{L}}=0.99$ and the AIC of the non-linear model is higher. All in all, the estimates for specification ii) do not support the presence of a non-linear relationship between RPI inflation and divisia money growth.

Next, we turn our attention to models of CPI inflation. Specification iii) allows for regimeswitching behaviour of CPI inflation depending on whether M4 growth is between (or outside of) the statistically significant thresholds of $\tau_{1}=7.09 \%$ and $\tau_{2}=10.28 \%$. The smoothing parameter, estimated at 5.32, suggests a relatively smooth transition between regimes. When M4 growth is within the inner regime, CPI inflation is driven by past inflation (which, in this case, is regime-dependent since $\left.\beta_{\pi, 1}=0.74\right)$, the output gap and the acceleration rate of global liquidity. The effect of global liquidity within this specification is statistically stronger (with a $t$-ratio=1.87) than that of the output gap effect (with a $t$-ratio=1.33). On the other hand, when M4 growth wanders outside of these regime boundaries, inflation becomes more persistent (since $\beta_{\pi, 2}=0.90$ ) and domestic liquidity conditions (money disequilibria and M4 growth) possess a statistically significant inflationary impact. Diagnostics for specification iii) in Table 3 reveal that the model passes the tests for AR and ARCH effects and the model parameters are time-invariant. Further, the model captures the non-linear relationship adequately and cannot be simplified to a linear model. Additionally, the model may not be simplified to a linear model and has a lower than 1 (i.e. $\widehat{\sigma_{N L}} / \widehat{\sigma_{L}}=0.81$ ) residual standard deviation ratio; this appears more than sufficient for the AIC to select the non-linear model.

Specification iv) in Table 3 uses divisia money as the transition variable. In this model, CPI inflation exhibits regime-switching behaviour depending on whether annual divisia money growth is between (or drifts away from) the regime boundaries $\tau_{1}=6.38 \%$ and $\tau_{2}=9.03 \%$. The estimated thresholds are statistically significant and the smoothing parameter is estimated at 550 suggesting an instantaneous switch as the regime boundaries are crossed. When divisia growth is contained between $6.38 \%$ and $9.03 \%$, CPI inflation is driven by the regimeindependent lagged inflation and the output gap; the latter effect is strong and statistically 
significant $\left(\beta_{\text {gap }, 1}=0.14\right.$, with a $t$-ratio of 2.9$)$. However, when divisia growth is either below $6.38 \%$ or above $9.03 \%$, the output gap effects diminish. In this regime, inflation is driven by lagged inflation, divisia growth, the acceleration rate of global divisia and money disequilibria. In this regime, divisia growth exerts a strong statistical impact on CPI inflation $\left(\beta_{D M, 2}=0.08\right.$, with a $t$-ratio of 4.9$)$. The impact of global liquidity is statistically weaker $\left(\beta_{G L}^{\text {divisia }}, 2=0.09 ; t\right.$-ratio $\left.=1.82\right)$. Diagnostics suggest that parameters are constant; the model sufficiently captures the regime-switching relationship and may not be simplified to a linear specification. Additionally, the model has a lower than 1 (i.e. $\widehat{\sigma_{N L}} / \widehat{\sigma_{L}}=0.91$ ) residual standard deviation ratio; this appears more than sufficient for the AIC to select the non-linear model. By comparing specification iii) with specification iv) and specification i) with specification ii), we also notice that inflation models with domestic M4 outperform those with divisia money in terms of diagnostics (AIC, adjusted $\mathrm{R}^{2}$ and regression standard error). Notice also that the CPI inflation model in iii) is the only model that passes both tests for AR and ARCH effects.

Following from the above estimates, a number of conclusions can be drawn. First, when M4 growth is contained within the $2.82 \%-9.54 \%$ boundaries, RPI inflation dynamics are driven by output gap effects (Table 3, specification i)). The same holds for CPI inflation when M4 growth is contained within the 7.09\%-10.28\% boundaries (Table 3, specification iii)); for this latter model and regime, CPI inflation is also driven by global liquidity effects. Second, outside the above mentioned threshold boundaries, RPI inflation is driven by M4 growth, global liquidity effects and money disequilibria (the latter suggesting that cointegration effects are "on" only when "too much" or "too little" money growth is observed). This is also true for CPI inflation except that in this case, global liquidity does not have an impact. Third, when divisia money growth is contained within the $6.38 \%-9.03 \%$ boundaries, CPI inflation is driven by output gap effects whereas, outside these boundaries, domestic divisia money growth and global liquidity (divisia) growth effects take over (Table 3, specification iv).

Overall, our results suggest that global liquidity does matter for domestic inflation dynamics over and above the impact of domestic liquidity. Nevertheless, both impacts depend on domestic liquidity thresholds. From a policy perspective, these thresholds need to be closely monitored by the Bank of England's MPC in an attempt to avoid strong inflationary pressures. To get a better idea of how global liquidity and domestic liquidity (M4 growth) have impacted on UK inflation over time, Figure 6 plots the implied regime-switching 
effects. These are reported for the CPI inflation model (Table 3, specification iii) which dominates (in terms of diagnostics) the remaining models. Regime-switching effects are calculated as $\beta_{G L^{\text {broad }}, 1} \alpha_{t-5}^{M 4}+\beta_{G L^{\text {broad }}, 2}\left(1-\alpha_{t-5}^{M 4}\right)$, with $\beta_{G L^{\text {broad }}, 1}=0.17, \beta_{G L^{\text {broad }}, 2}=0$, and $\beta_{M 4,1} \alpha_{t-5}^{M 4}+\beta_{M 4,2}\left(1-\alpha_{t-5}^{M 4}\right)$, with $\beta_{M 4,1}=0, \beta_{M 4,2}=0.07, \tau_{1}=7.09 \%, \tau_{2}=10.28 \%$ and $\gamma=5.32$ respectively. Figure 6 shows that when M4 growth exceeds the estimated boundaries, its movements drive inflation dynamics. On the other hand, when M4 growth is contained within the regime boundaries, global liquidity effects have an increasing role. Notice that between 2000 and early 2008 (largely prior to the financial crisis), M4 growth fluctuated initially close to the lower regime bound and then close to the upper regime bound; in this case, inflation dynamics were dictated both by global liquidity, domestic money effects (and indeed output gap movements). Since 2009, however, and despite QE injections, domestic M4 growth has remained weak and below the lower regime boundary. In this case, the very (admittedly slow) surge in M4 growth has impacted on rising inflation, whereas, global liquidity effects have been negligible. Nevertheless, M4 growth still remains low which explains why a significant surge in UK inflation has been avoided. Notice that since 2012, CPI inflation recorded an average of $2.5 \%$ (only 0.5 percentage points above the $2 \%$ target), and, in fact, moved below the target throughout 2014.

\section{Conclusions}

This paper provides an empirical comparison of the effects of domestic and global liquidity effects through the lens of money aggregates on UK inflation. Two measures of global liquidity were constructed, broad money global liquidity and divisia money global liquidity, respectively. We find statistically significant evidence that global liquidity yields inflationary pressures in the UK over and above the impact of domestic money growth, output gap and money disequilibria (the latter accounting for the property sector and financial asset markets). All reported effects are regime-switching as they depend on whether domestic money growth is contained within or exceeds threshold boundaries. Our empirical results also suggest that M4 money growth dominates divisia money growth in modelling UK inflation.

From a policy perspective, we note the obvious: the Bank of England's MPC cannot target global liquidity. Nevertheless, it makes sense for the MPC to monitor domestic money growth as the inflationary effects of both domestic money and global liquidity depend on money growth boundaries. Our empirical results show that UK CPI inflation dynamics are currently governed by a monetary regime in which M4 growth is weak. In this very regime, 
the impact of both output gap and global liquidity is negligible. Therefore, with broad money (M4) growth remaining largely subdued, our findings (arguably) point against the immediate risk of strong inflationary pressures.

Our work can be extended in a number of directions. First, to further enhance our understanding of broad and divisia money aggregates and inflation, it would be interesting to examine how the non-linear models employed here forecast inflation out-of-sample. Second, a more definitive picture on the relationship between broad and divisia money and inflation could emerge by employing a regime-switching VAR model in inflation, the policy interest rate, the output gap and domestic money growth conditional on exogenous global liquidity effects. Third, both global and domestic money considerations could be employed in modelling inflation beyond the UK economy. These issues are left for future research.

\section{Acknowledgements}

Michael Ellington acknowledges financial support from ESRC's North West Doctoral Training Centre. We thank Chris Florackis, Cherif Guermat, Stephen Millard, Chardin WeseSimen and seminar participants at Bank of England for useful comments and suggestions on an earlier version of the paper. Any remaining errors are our own.

\section{References}

Ahmad, A.H., Martin, C.I. and Milas, C. 2014. The Policy Window: The Impact of Financial Stress in the UK. Working Paper No. 17/14. Department of Economics, University of Bath.

Baks, K., and Kramer, C.F. 1999. Global liquidity and asset prices: Measurement, implications, and spillovers: International Monetary Fund Working Paper No. 168.

Beckmann, J., Belke, A., and Czudaj, R. 2014. Does global liquidity drive commodity prices? Journal of Banking and Finance (forthcoming).

Belke, A., Orth, W., and Setzer, R. 2010. Liquidity and the dynamic pattern of asset price adjustment: A global view. Journal of Banking and Finance, 34(8): 1933-1945.

Belongia, M.T. 1996. Measurement matters: Recent results from monetary economics reexamined. Journal of Political Economy, 104(5): 1065-1083. 
Beyer, A. 2009. A stable model for Euro Area money demand: Revisiting the role of wealth: European Central Bank Working Paper No. 1111.

Blanchard, O., 1988. Why does money affect output? in B. Friedman and F. Hahn (eds) Handbook of Monetary Economics, North-Holland, Amsterdam, 779-835.

Boone, L., and Van den Noord, P. 2008. Wealth effects on money demand in the euro area. Empirical Economics, 34(3): 525-536.

Borio, C.E., and Filardo, A.J. 2007. Globalisation and inflation: New cross-country evidence on the global determinants of domestic inflation: Bank for International Settlements, Working Paper No. 227.

Brock, W., Scheinkman, J.A., Dechert, W.D., and LeBaron, B. 1996. A test for independence based on the correlation dimension. Econometric Reviews, 15(3): 197235.

Ciccarelli, M., and Mojon, B. 2010. Global inflation. The Review of Economics and Statistics, 92(3): 524-535.

Clements, M. P., and Sensier, M. 2003. Asymmetric output-gap effects in Phillips Curve and mark-up pricing models: Evidence for the US and the UK. Scottish Journal of Political Economy, 50(4): 359-374.

Darrat, A.F., Chopin, M.C. and Lobo, B.J. 2005. Money and Macroeconomic Performance: Revisiting Divisia Money. The Review of Financial Economics, 14, 93 101.

D'Agostino, A., and Surico, P. 2009. Does global liquidity help to forecast US inflation? Journal of Money, Credit and Banking, 41(2-3): 479-489.

De Santis, R.A., Favero, C.A., and Roffia, B. 2013. Euro area money demand and international portfolio allocation: A contribution to assessing risks to price stability. Journal of International Money and Finance, 32: 377-404.

Drake, L., and Mills, T.C. 2005. A new empirically weighted monetary aggregate for the United States. Economic Inquiry, 43(1): 138-157.

Dreger, C., and Wolters, J. 2010. Investigating M3 money demand in the euro area. Journal of International Money and Finance, 29(1): 111-122.

Dreger, C., and Wolters, J. 2014. Money demand and the role of monetary indicators in forecasting euro area inflation. International Journal of Forecasting, 30(2): 303-312.

Eitrheim, Ø. and Teräsvirta, T. 1996. Testing the adequacy of smooth transition autoregressive models. Journal of Econometrics, 74, 59-75. 
Elliott, G., Rothenberg, T.J., and Stock, J.H. 1996. Efficient tests for an autoregressive unit root. Econometrica, 64(4): 813-836.

Engle, R.F., and Granger, C.W. 1987. Co-integration and error correction: representation, estimation, and testing. Econometrica, 55(2): 251-276.

Florackis, C., Giorgioni, G., Kostakis, A., and Milas, C. 2014. On stock market illiquidity and real-time GDP growth. Journal of International Money and Finance, 44: 210229.

Giese, J.V., and Tuxen, C.K. 2007. Global liquidity and asset prices in a cointegrated VAR. Nuffield College, University of Oxford, and Department of Economics, Copenhagen University. Available from: http://www.edge-page.net/jamb2007/papers/GieseandTuxen06-07-2007.pdf

Goldstein, M. 1998. The Asian financial crisis. Peterson Institute for International Economics, Policy Brief 98-1.

Goodhart, C., and Hofmann, B. 2008. House prices, money, credit, and the macroeconomy. Oxford Review of Economic Policy, 24(1): 180-205.

Granger, C.W.J., and Teräsvirta, T. 1993. Modeling Nonlinear Economic Relationships. Oxford: Oxford University Press.

Hancock, M. 2005. Divisia money. Bank of England Quarterly Bulletin, Spring, 39-46.

Hendry, D.F. 2001. Modelling UK inflation, 1875-1991. Journal of Applied Econometrics, 16(3): 255-275.

Hodrick, R.J., and Prescott, E.C. 1997. Postwar US business cycles: an empirical investigation. Journal of Money, Credit and Banking, 29: 1-16.

Johansen, S. 1988. Statistical analysis of cointegration vectors. Journal of Economic Dynamics and Control, 12(2): 231-254.

Johansen, S. 1995. Likelihood-based inference in cointegrated vector autoregressive models. Oxford University Press, Oxford.

Kwiatkowski, D., Phillips, P. C., Schmidt, P., and Shin, Y. 1992. Testing the null hypothesis of stationarity against the alternative of a unit root: How sure are we that economic time series have a unit root? Journal of Econometrics, 54(1): 159-178.

Lin, C.-F.J., and Teräsvirta, T. 1994. Testing the constancy of regression parameters against continuous structural change. Journal of Econometrics, 62(2): 211-228.

Lucas Jr, R. E. 2000. Inflation and welfare. Econometrica, 68(2): 247-274. 
MacKinnon, J.G. 1991. Critical Values for Cointegration Tests, Chapter 13 in RF Engle and CWJ Granger (eds.) Long-run Economic Relationships: Readings in Cointegration: Oxford University Press, 267-276.

Martin, C. and Milas, C. 2012. Quantitative Easing: A sceptical survey. Oxford Review of Economic Policy, 28(4): 750-764.

Milas, C. 2009. Does high M4 money growth trigger large increases in UK inflation? Evidence from a regime-switching model. Oxford Economic Papers, 61(1): 168-182.

Osborn, D.R., and Sensier, M. 2009. UK inflation: persistence, seasonality and monetary policy. Scottish Journal of Political Economy, 56(1): 24-44.

Rüffer, R., and Stracca, L. 2006. What is global excess liquidity, and does it matter?: European Central Bank, Working Paper No. 696.

Setzer, R. and Greiber, C. 2007. Money and Housing: Evidence for the Euro Area and the US: Deutsche Bundesbank Discussion Paper No. 12/2007.

Sousa, J., and Zaghini, A. 2008. Monetary policy shocks in the euro area and global liquidity spillovers. International Journal of Finance and Economics, 13(3): 205-218.

Sousa, R. M. 2010. Housing wealth, financial wealth, money demand and policy rule: evidence from the euro area. The North American Journal of Economics and Finance, 21(1): 88-105.

Stracca, L. 2004. Does Liquidity Matter? Properties of a Divisia Monetary Aggregate in the Euro Area. Oxford Bulletin of Economics and Statistics, 66(3): 309-331.

van Dijk, D., Teräsvirta, T., and Franses, P. H. 2002. Smooth transition autoregressive models - a survey of recent developments. Econometric Reviews, 21(1): 1-47.

Walsh, C. (2003). Speed Limit Policies: The Output Gap and Optimal Monetary Policy. The American Economic Review, 93(1): 265-278. 


\section{Appendix}

Data sources and definitions of money aggregate used in the constructions of global liquidity measures considered in this paper are reported in the following Table. For Euro area GDP pre-1995 we spliced the 11 country's aggregated GDP that joined the currency union in 1999 with the published Euro area GDP series commencing from 1995Q1.

\begin{tabular}{|c|c|c|c|}
\hline Variable & \multicolumn{2}{|l|}{ Definition } & Source \\
\hline Divisia money aggregate & \multicolumn{2}{|c|}{ USA: Divisia M3 including Treasuries } & $\begin{array}{l}\text { Centre for financial } \\
\text { stability }\end{array}$ \\
\hline \multirow[t]{4}{*}{ Broad money aggregate } & \multicolumn{2}{|l|}{ USA: M2 } & US Federal Reserve \\
\hline & \multicolumn{2}{|l|}{ Japan: M2 } & OECD \\
\hline & \multicolumn{2}{|l|}{ Canada: M2+ } & OECD \\
\hline & \multicolumn{2}{|l|}{ Euro Area: M3 } & Eurostat \\
\hline \multirow[t]{15}{*}{ GDP } & \multicolumn{2}{|l|}{ USA } & OECD \\
\hline & \multicolumn{2}{|l|}{ Japan } & OECD \\
\hline & \multicolumn{2}{|l|}{ Canada } & OECD \\
\hline & \multicolumn{2}{|l|}{ Euro area (post-(1995Q1) } & OECD \\
\hline & \multirow[t]{11}{*}{ Euro area (pre-1995Q1) } & Austria & OECD \\
\hline & & Belgium & OECD \\
\hline & & Finland & OECD \\
\hline & & France & OECD \\
\hline & & Germany & OECD \\
\hline & & Ireland & OECD \\
\hline & & Italy & OECD \\
\hline & & Luxembourg & OECD \\
\hline & & Netherlands & OECD \\
\hline & & Portugal & OECD \\
\hline & & Spain & OECD \\
\hline \multirow{5}{*}{$\begin{array}{l}\text { Consumer price indices } \\
\text { (HICP for the Euro area) }\end{array}$} & \multicolumn{2}{|l|}{ USA } & OECD \\
\hline & \multicolumn{2}{|l|}{$\begin{array}{l}\text { UK } \\
\text { Japan }\end{array}$} & OECD \\
\hline & & & OECD \\
\hline & \multicolumn{2}{|l|}{ Canada } & OECD \\
\hline & \multicolumn{2}{|l|}{ Euro Area } & Data-Stream \\
\hline \multirow[t]{4}{*}{ Spot exchange rates } & \multicolumn{2}{|l|}{ USA } & Bank of England \\
\hline & \multicolumn{2}{|l|}{ Japan } & Bank of England \\
\hline & \multicolumn{2}{|l|}{ Canada } & Bank of England \\
\hline & \multicolumn{2}{|l|}{ Euro } & Bank of England \\
\hline
\end{tabular}


Table 1: Stationarity tests for the money disequilibrium constructions

\begin{tabular}{|c|c|c|c|c|}
\hline \multirow[b]{3}{*}{ EGS (with intercept) ${ }^{\mathrm{a}}$} & \multicolumn{2}{|c|}{ Sample: 1983Q1-2014Q1 } & \multicolumn{2}{|c|}{ Sample: 1988Q1-2014Q1 } \\
\hline & diseq $_{t}^{r p i, M 4}$ & diseq $q_{t}^{r p i, d m}$ & diseq $q_{t}^{c p i, M 4}$ & diseq $_{t}^{c p i, d m}$ \\
\hline & & & & \\
\hline \multicolumn{5}{|l|}{ Lag length } \\
\hline 0 & -1.27 & $-2.07 * *$ & -1.00 & -1.49 \\
\hline 2 & $-1.71 *$ & $-2.31 * *$ & $-1.70 *$ & $-2.07 * *$ \\
\hline 4 & $-1.65 *$ & $-1.79 *$ & $-1.84 *$ & $-2.15 * *$ \\
\hline 6 & -1.33 & -1.56 & $-1.88^{*}$ & $-2.15 * *$ \\
\hline KPSS (with intercept) ${ }^{\mathrm{b}}$ & 0.13 & 0.13 & 0.15 & 0.20 \\
\hline $\begin{array}{l}\text { Bandwidth (Newey-West automatic } \\
\text { selection) }\end{array}$ & 8 & 8 & 8 & 8 \\
\hline \multicolumn{5}{|l|}{ ERS (with intercept) ${ }^{\mathrm{c}}$} \\
\hline \multicolumn{5}{|l|}{ Lag length } \\
\hline 0 & 10.26 & $4.11^{*}$ & 15.58 & 5.04 \\
\hline 2 & 4.68 & $2.84 * *$ & 4.83 & $2.61 * *$ \\
\hline 4 & $3.77 *$ & $2.92 * *$ & $2.83 * *$ & $1.84^{* * * *}$ \\
\hline 6 & 4.46 & $2.53 * *$ & $2.20 * *$ & $1.44 * * *$ \\
\hline
\end{tabular}

${ }^{\mathrm{a}}$ The $10 \%, 5 \%$ and $1 \%$ critical values for the ADF-GLS test are $-1.61,-1.94$ and -2.58 , respectively

${ }^{\mathrm{b}}$ The $10 \%, 5 \%$ and $1 \%$ critical values for the KPSS test are $0.347,0.463$ and 0.739 , respectively

${ }^{\mathrm{c}}$ The $10 \%, 5 \%$ and $1 \%$ critical values for the ERS point optimal are 4.20, 3.12 and 1.94, respectively

Notes: This Table reports stationarity tests upon the money disequilibrium constructions from (1)-(4). The EGS test is a unit root test developed by Elliot et al (1996) which de-trends the residuals before running the test regression. The KPSS test is an LM-type test proposed by Kwiatkowski et al (1992) with the null hypothesis that the data is trend stationary. The ERS test (see Elliot et al (1996)) works off quasi-differenced data before running the test regression. *, ** and *** denote a rejection of the null hypothesis at $10 \%, 5 \%$ and $1 \%$ significance, respectively. 


\section{Table 2: Linear estimates of UK inflation}

$$
\begin{aligned}
& \text { i) } \pi_{t}^{r p i}=\beta_{0}+\beta_{\pi} \pi_{t-1}^{r p i}+\beta_{M 4} M 4_{t-1}+\beta_{g a p} \Delta g a p_{t-1}+\beta_{G L} \text { broad } G L_{t-4}^{\text {broad }}+\beta_{\text {diseq }} \text { diseq } t_{t-3}^{r p i, M 4}+v_{t} \\
& \text { ii) } \pi_{t}^{r p i}=\beta_{0}+\beta_{\pi} \pi_{t-1}^{r p i}+\beta_{D M} D M_{t-1}+\beta_{g a p} \Delta g a p_{t-1}+\beta_{G L} \text { divisia } \Delta G L_{t-1}^{\text {divisia }}+\beta_{\text {diseq }} \text { diseq } q_{t-3}^{r p i, d m}+v_{t}
\end{aligned}
$$

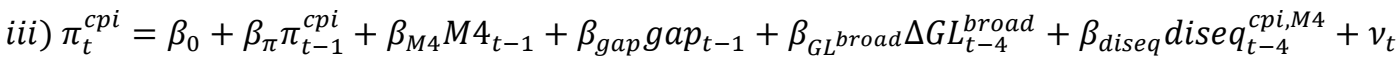

$$
\begin{aligned}
& \text { iv) } \pi_{t}^{c p i}=\beta_{0}+\beta_{\pi} \pi_{t-1}^{c p i}+\beta_{D M} D M_{t-2}+\beta_{g a p} g a p_{t-4}+\beta_{G L} \text { divisia } \Delta G L_{t-1}^{\text {divisia }}+\beta_{\text {diseq }} \text { diseq } q_{t-3}^{c p i, d m}+v_{t}
\end{aligned}
$$

\begin{tabular}{|c|c|c|c|c|}
\hline & \multicolumn{2}{|c|}{ Sample: 1983Q4-2014Q1 } & \multicolumn{2}{|c|}{ Sample: 1989Q2-2014Q1 } \\
\hline & i) & ii) & iii) & iv) \\
\hline$\beta_{0}$ & $-0.01(-0.06)$ & $-0.002(-0.01)$ & $-0.15(-0.94)$ & $-0.05(-0.26)$ \\
\hline$\beta_{\pi}$ & $0.88(18.86)$ & $0.88(15.17)$ & $0.91(16.37)$ & $0.94(19.52)$ \\
\hline$\beta_{M 4}$ & $0.03(1.29)$ & & $0.05(1.76)$ & \\
\hline$\beta_{D M}$ & & $0.06(2.61)$ & & $0.03(1.12)$ \\
\hline$\beta_{\text {gap }}$ & $0.43(3.02)$ & $0.31(3.45)$ & $0.03(1.13)$ & $0.04(1.44)$ \\
\hline$\beta_{G L^{\text {broad }}}$ & $0.03(0.80)$ & & $0.07(0.98)$ & \\
\hline$\beta_{G L}^{\text {divisia }}$ & & $0.08(1.37)$ & & $0.09(1.98)$ \\
\hline$\beta_{\text {diseq }}$ & $0.03(0.94)$ & $0.05(1.11)$ & $0.03(1.31)$ & $0.02(0.71)$ \\
\hline $\bar{R}^{2}$ & 0.86 & 0.87 & 0.91 & 0.90 \\
\hline Regression standard error & 0.71 & 0.69 & 0.52 & 0.52 \\
\hline AIC & 2.20 & 2.13 & 1.57 & 1.59 \\
\hline $\begin{array}{l}\text { Parameter Constancy F-test } \\
\text { [p-value] }\end{array}$ & 0.00 & 0.27 & 0.00 & 0.00 \\
\hline$A R(4)[p$-value $]$ & 0.00 & 0.00 & 0.03 & 0.00 \\
\hline $\begin{array}{l}\text { ARCH(4) [p-value] } \\
B D S\end{array}$ & 0.00 & 0.02 & 0.01 & 0.07 \\
\hline Dimension & [bootstrapped & ues] & & \\
\hline 2 & 0.00 & 0.00 & 0.02 & 0.06 \\
\hline 3 & 0.01 & 0.04 & 0.07 & 0.28 \\
\hline 4 & 0.01 & 0.07 & 0.07 & 0.39 \\
\hline 5 & 0.00 & 0.04 & 0.02 & 0.18 \\
\hline 6 & 0.00 & 0.04 & 0.01 & 0.11 \\
\hline
\end{tabular}

Dependent variable: $\quad$ RPI inflation rate CPI inflation rate

Notes: This Table shows estimates of linear models for UK RPI and CPI inflation from 1983Q4-2014Q1 and 1989Q22014Q1, respectively. $t$-ratios are given in parentheses (based on Newey-West Heteroskedasticity and Autocorrelation robust standard errors). AIC stands for Akaike Information Criterion. Parameter constancy is an F-test for parameter constancy testing the statistical significance of the cross product of all regressors in the linear model and a time trend, a quadratic trend and a cubic trend (see Lin and Teräsvirta (1994)). AR(4) is an F-test for fourth order serial correlation. ARCH(4) is an $F$-test for fourth order ARCH effects. $B D S$ (see Brock et al (1996)) is a test for independence of the residuals from the linear model based on correlation dimension 2-6; bootstrapped $p$-values are reported based on 10,000 repetitions. 
Table 3: Non-linear estimates of UK inflation

Dependent variable: RPI inflation rate

Sample:1983Q4-2014Q1

\begin{tabular}{|c|c|c|c|c|}
\hline & \multicolumn{2}{|c|}{ sample:1983Q4-2014Q1 } & \multicolumn{2}{|c|}{ sample: 1989Q2-2014Q1 } \\
\hline & i) & ii) & iii) & iv) \\
\hline$\beta_{0}$ & $0.44(3.46)$ & $-0.20(-0.87)$ & $-0.09(-0.77)$ & $-0.06(-0.57)$ \\
\hline$\beta_{\pi}$ & $0.80(19.10)$ & $0.85(14.47)$ & & $0.89(17.91)$ \\
\hline$\beta_{D M}$ & & $0.08(3.18)$ & & \\
\hline Regime when & $\tau_{1}<M 4_{t-1}<\tau_{2}$ & $\operatorname{diseq}_{t-2}^{r p i, d m}<\tau$ & $\tau_{1}<M 4_{t-5}<\tau_{2}$ & $\tau_{1}<D M_{t-2}<\tau_{2}$ \\
\hline$\beta_{\pi, 1}$ & & & $0.74(4.44)$ & \\
\hline$\beta_{g a p, 1}$ & $0.50(3.15)$ & $0.15(1.12)$ & $0.26(1.33)$ & $0.14(2.90)$ \\
\hline$\beta_{G L^{\text {broad }}, 1}$ & & & $0.17(1.87)$ & \\
\hline Regime when & $\begin{array}{l}M 4_{t-1} \text { is outside of } \\
\left(\tau_{1}, \tau_{2}\right)\end{array}$ & $\operatorname{diseq}_{t-2}^{r p i, d m}>\tau$ & $\begin{array}{l}M 4_{t-5} \text { is outside of } \\
\left(\tau_{1}, \tau_{2}\right)\end{array}$ & $\begin{array}{l}D M_{t-2} \text { is outside of } \\
\left(\tau_{1}, \tau_{2}\right)\end{array}$ \\
\hline$\beta_{\pi, 2}$ & & & $0.90(19.60)$ & \\
\hline$\beta_{M 4,2}$ & $0.04(1.51)$ & & $0.07(2.82)$ & \\
\hline$\beta_{D M, 2}$ & & & & $0.08(4.89)$ \\
\hline$\beta_{G L^{\text {broad }_{, 2}}}$ & $0.09(1.55)$ & & & \\
\hline$\beta_{G L}$ divisia $_{, 2}$ & & $0.17(1.76)$ & & $0.09(1.82)$ \\
\hline$\beta_{\text {diseq,2 }}$ & $0.09(5.36)$ & $0.12(1.54)$ & $0.03(1.98)$ & $0.03(1.15)$ \\
\hline$\gamma$ & $502.02(0.04)$ & $8.41(0.36)$ & $5.32(1.63)$ & $550.0(-)^{*}$ \\
\hline$\tau$ & & $-0.52(-0.42)$ & & \\
\hline$\tau_{1}$ & $2.82(17.44)$ & & $7.09(5.96)$ & $6.38(4.26)$ \\
\hline$\tau_{2}$ & $9.54(19.68)$ & & $10.28(7.75)$ & $9.03(9.82)$ \\
\hline $\bar{R}^{2}$ & 0.90 & 0.87 & 0.94 & 0.92 \\
\hline $\begin{array}{l}\text { Regression standard } \\
\text { error }\end{array}$ & 0.61 & 0.68 & 0.43 & 0.48 \\
\hline$A I C$ & 1.93 & 2.14 & 1.24 & 1.46 \\
\hline Parameter Constancy & 0.25 & 0.25 & 0.45 & 0.23 \\
\hline$F$-test [p-value] & & & & \\
\hline$A R(4)$ [p-value] & 0.00 & 0.00 & 0.13 & 0.01 \\
\hline$A R C H(4)$ [p-value] & 0.20 & 0.01 & 0.19 & 0.03 \\
\hline $\begin{array}{l}\text { No remaining non- } \\
\text { linearity } F \text {-test [p- } \\
\text { value] }\end{array}$ & 0.34 & 0.00 & 0.85 & 0.23 \\
\hline $\begin{array}{l}\text { Test against linear } \\
\text { model F-test[p-value] }\end{array}$ & 0.01 & 0.90 & 0.01 & 0.04 \\
\hline $\begin{array}{l}\widehat{\sigma_{N L}} / \widehat{\sigma_{L}} \\
B D S\end{array}$ & 0.85 & 0.99 & 0.81 & 0.91 \\
\hline Dimension & [bootstrapped p-values] & & & \\
\hline 2 & 0.06 & 0.00 & 0.53 & 0.01 \\
\hline 3 & 0.10 & 0.02 & 0.94 & 0.04 \\
\hline 4 & 0.11 & 0.07 & 0.67 & 0.08 \\
\hline 5 & 0.02 & 0.03 & 0.51 & 0.05 \\
\hline 6 & 0.02 & 0.02 & 0.32 & 0.04 \\
\hline $\begin{array}{l}\text { Notes: This Table shows } \\
\text { ratios are given in parenthe } \\
\text { model in iii)). Parameter } \\
\text { regressors in the non-linear } \\
\text { ARCH( } 4) \text { is an } F \text {-test for } \\
\text { significance of the cross pro } \\
\text { al }(2002)) \text {. Test against line } \\
\text { estimated volatility within t } \\
\text { for independence of the res } \\
10,000 \text { repetitions. *Impose }\end{array}$ & $\begin{array}{l}\text { stimates of non-linear mod } \\
\text { s (these are based on Newe } \\
\text { nstancy is an } F \text {-test for } \mathrm{p} \\
\text { oodel and time trend, (see } \\
\text { ourth order ARCH effect } \\
\text { uct of the regressors in the } \\
\text { ir model is an } F \text {-test indica } \\
\text { e residuals generated from } \\
\text { luals from the linear mode } \\
\text { value. We failed to get a cc }\end{array}$ & $\begin{array}{l}\text { ls for UK inflation fr } \\
\text {-West Heteroskedastic } \\
\text { rameter constancy tes } \\
\text { trheim and Teräsvirta } \\
\text { No remaining non-li } \\
\text { on-linear model and th } \\
\text { ng whether the model } \\
\text { le non-linear model ar } \\
\text { based on correlation } \\
\text { lverging estimate so w }\end{array}$ & $\begin{array}{l}\text { 1983Q4-2014Q1 and } 1985 \\
\text { and Autocorrelation robust } \\
\text { the statistical significanc } \\
96 \text { )). AR(4) is an } F \text {-test for } 1 \\
\text { trity is an F-test which in } \\
\text { ansition variable of the non } \\
\text { ay be simplified to a linear } \\
\text { he linear baseline. BDS (se } \\
\text { ension } 2-6 \text {; bootstrapped } p \\
\text { llowed a grid search in the }\end{array}$ & $\begin{array}{l}\text {-2014Q1, respectively. } t \text { - } \\
\text { ndard errors except for the } \\
\mathrm{f} \text { the cross product of all } \\
\text { rth order serial correlation. } \\
\text { lves testing the statistical } \\
\text { lear model (see van Dijk et } \\
\text { del. } \widehat{\sigma_{N L}} / \widehat{\sigma_{L}} \text { is the ratio of } \\
\text { rock et al }(1996) \text { ) is a test } \\
\text { lues are reported based on } \\
\text { ge }[0.1,550] \text { and fixed the }\end{array}$ \\
\hline
\end{tabular}

Notes: This Table shows estimates of non-linear models for UK inflation from 1983Q4-2014Q1 and 1989Q2-2014Q1, respectively. $t$ ratios are given in parentheses (these are based on Newey-West Heteroskedasticity and Autocorrelation robust standard errors except for the model in iii)). Parameter constancy is an $F$-test for parameter constancy testing the statistical significance of the cross product of all regressors in the non-linear model and time trend, (see Eitrheim and Teräsvirta (1996)). $A R(4)$ is an $F$-test for fourth order serial correlation. $A R C H(4)$ is an $F$-test for fourth order ARCH effects. No remaining non-linearity is an $F$-test which involves testing the statistical significance of the cross product of the regressors in the non-linear model and the transition variable of the non-linear model (see van Dijk et al (2002)). Test against linear model is an F-test indicating whether the model may be simplified to a linear model. $\widehat{\sigma_{N L}} / \widehat{\sigma_{L}}$ is the ratio of estimated volatility within the residuals generated from the non-linear model and the linear baseline. BDS (see Brock et al (1996)) is a test for independence of the residuals from the linear model based on correlation dimension 2-6; bootstrapped $p$-values are reported based on 10,000 repetitions. *Imposed value. We failed to get a converging estimate so we followed a grid search in the range [0.1, 550] and fixed the $\gamma$ parameter to the one that delivers the best fit for the estimated model.

CPI inflation rate

Sample: 1989Q2-2014Q1 


\section{Figure 1: Data used for models of UK RPI inflation}

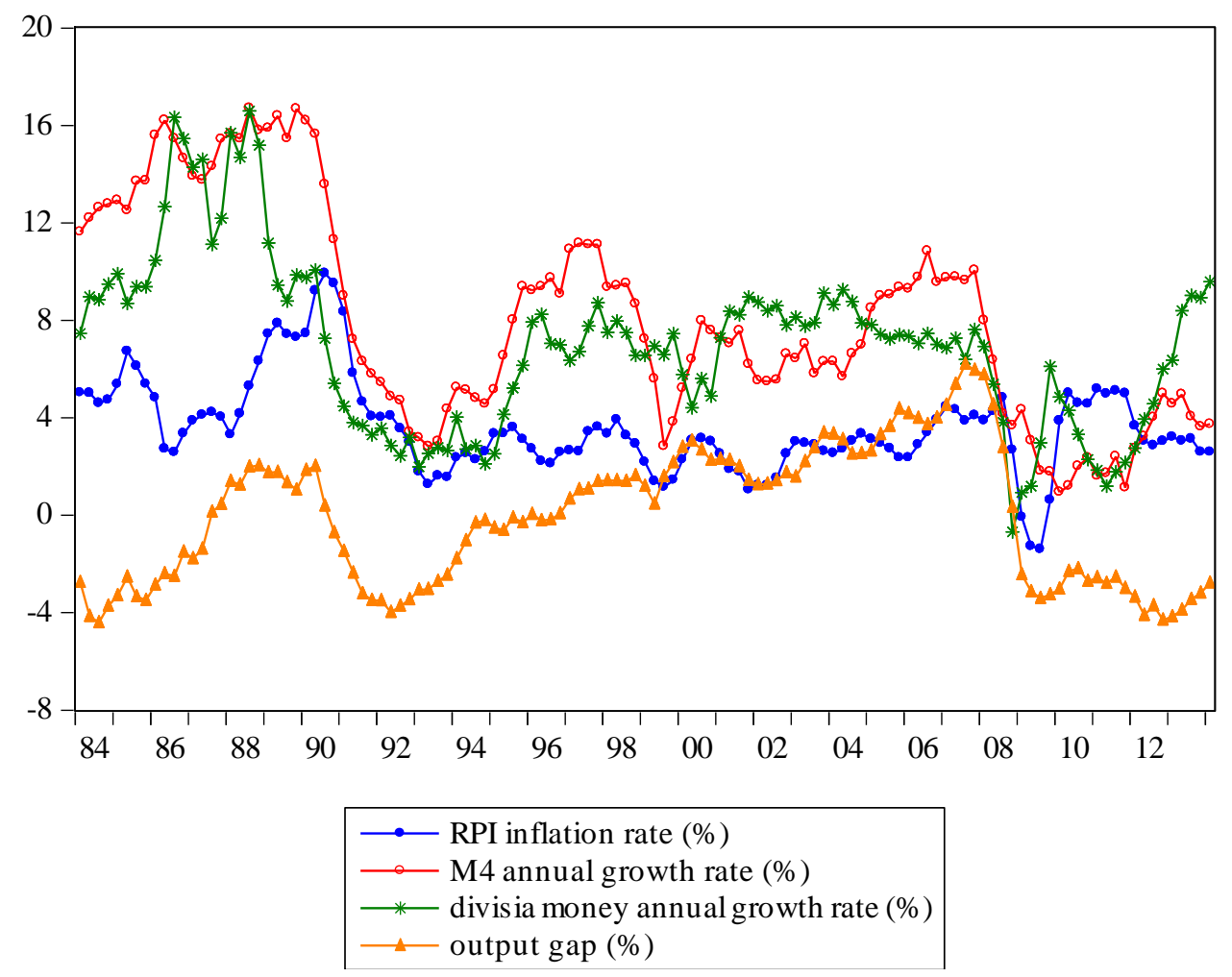

Notes: This Figure shows the time-series data used to model UK RPI inflation from 1983Q4-2014Q1 (excluding the money disequilibrium and global liquidity constructions). 


\section{Figure 2: Data used for models of UK CPI inflation}

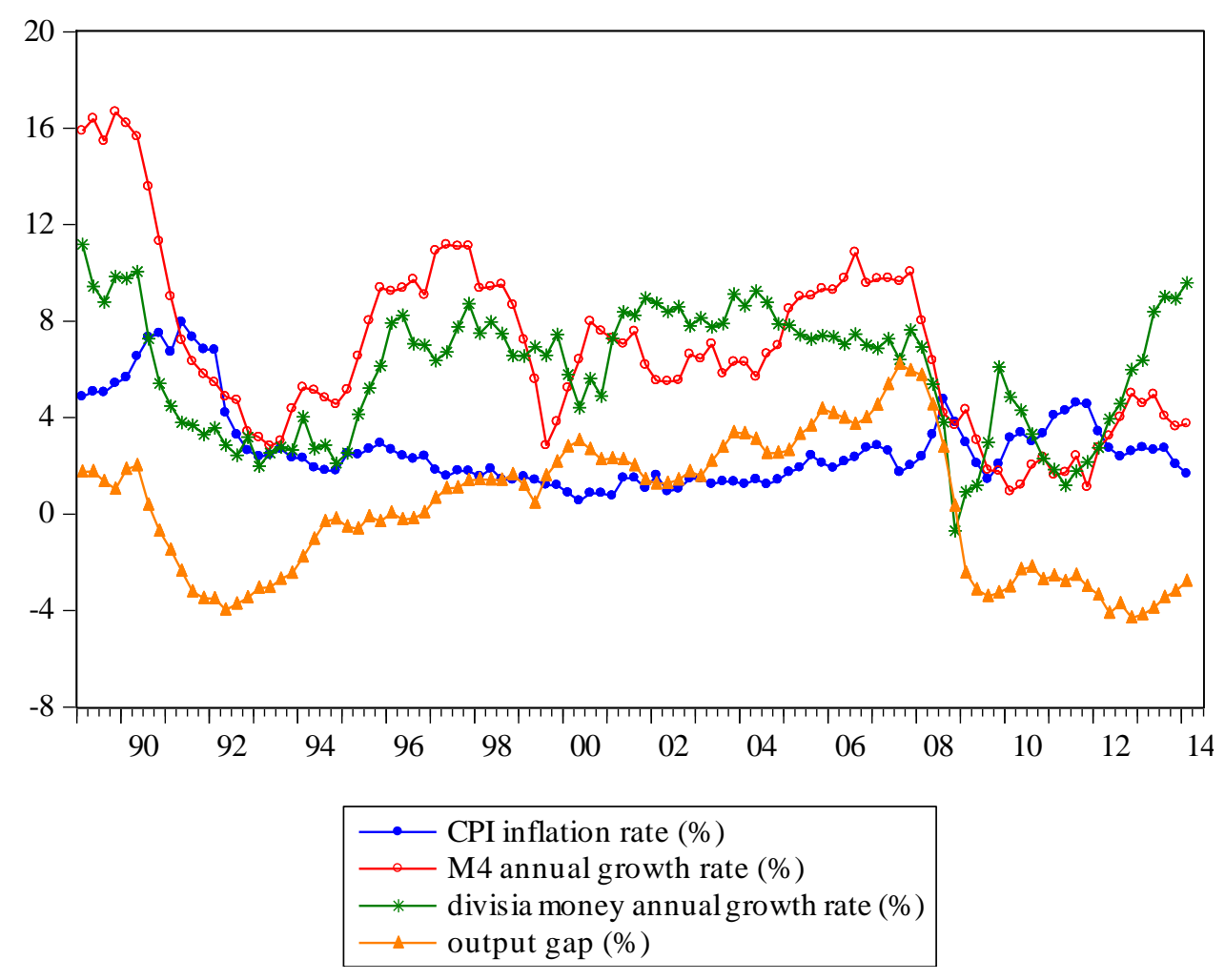

Notes: This Figure shows the time-series data used to model UK CPI inflation from 1989Q2-2014Q1 (excluding the money disequilibrium and global liquidity constructions). 
Figure 3: Money disequilibrium (\%) constructions using the Retail Price index as a proxy for UK prices

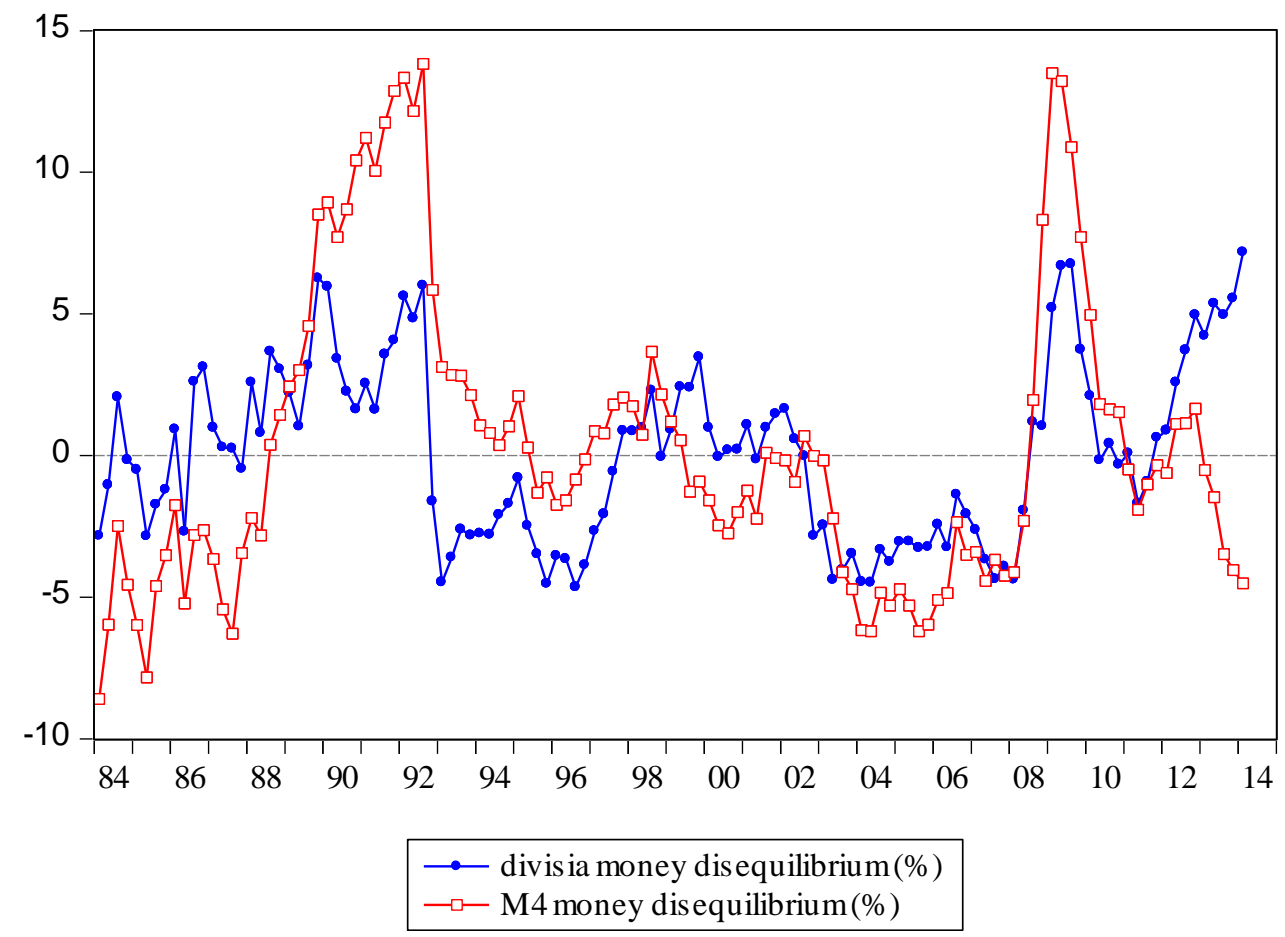

Notes: This Figure shows the money disequilibrium constructions using the log level of the Retail Price Index as a proxy for UK prices from 1983Q4-2014Q1. M4 money disequilibrium corresponds to equation (1) in main text. Divisia money disequilibrium corresponds to equation (2) in main text. 
Figure 4: Money disequilibrium (\%) constructions using the Consumer Price index as a proxy for UK prices

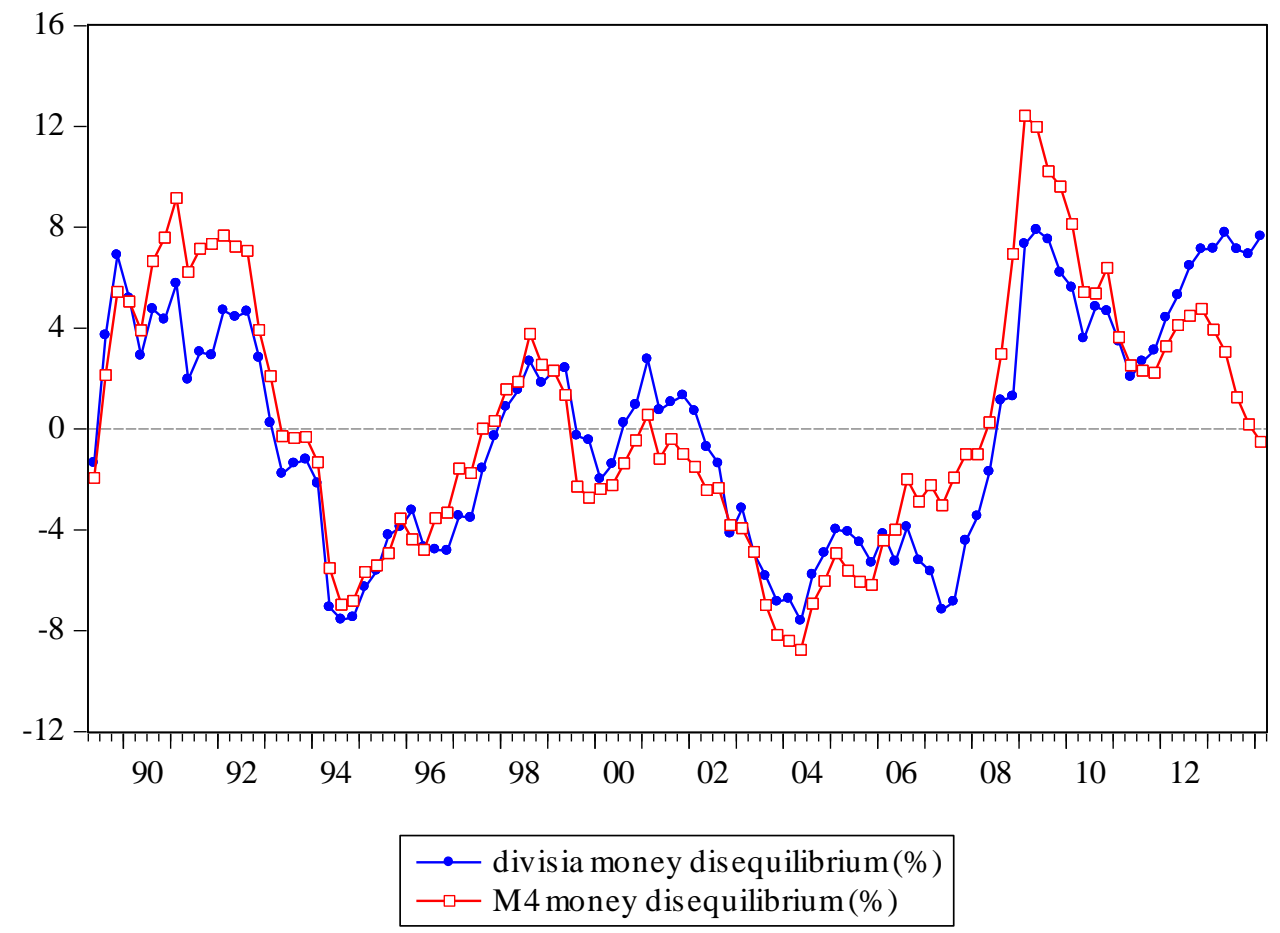

Notes: This Figure shows the money disequilibrium constructions using the log level of the Consumer Price Index as a proxy for UK prices from 1989Q2-2014Q1. M4 money disequilibrium corresponds to equation (3) in main text. Divisia money disequilibrium corresponds to equation (4) in main text. 
Figure 5: Measures of global liquidity. Annual growth (\%)

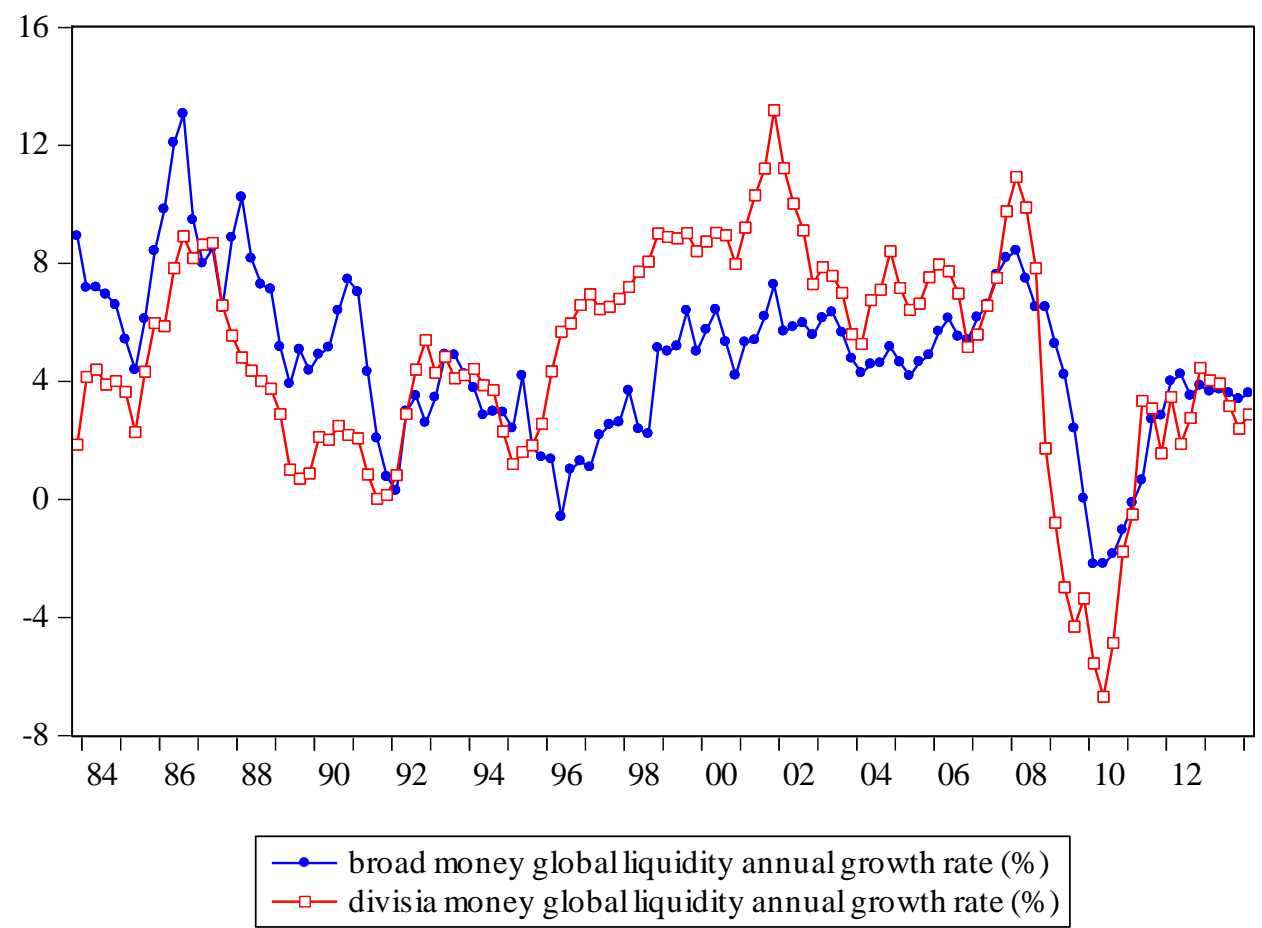

Notes: This Figure shows the constructions of broad money global liquidity and divisia money global liquidity annual growth rates over 1983Q4-2014Q1. 
Figure 6: The regime switching impact of broad money global liquidity and domestic M4 growth on UK CPI inflation, 1989Q2-2014Q1

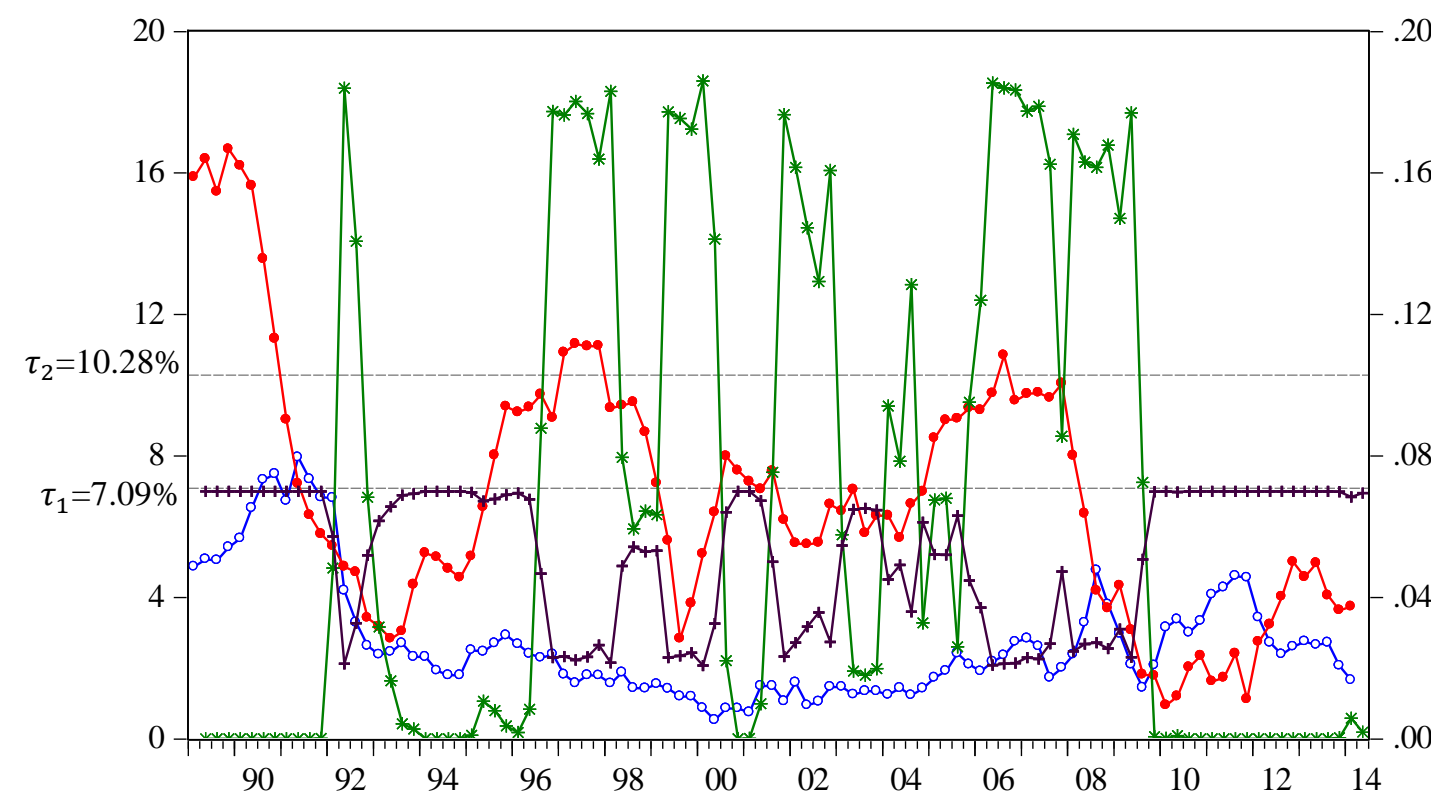

$$
\begin{aligned}
& \text { — CPI inflation rate (\%) (LHS axis) } \\
& \longrightarrow \text { M4 annual growth rate (\%) (LHS axis) } \\
& \text { —- regime-s witching impact of broad money global liquidity (RHS axis) } \\
& \longrightarrow \text { regime-s witching impact of M4 annual growth (RHS axis) }
\end{aligned}
$$

Notes: This figure shows the regime-switching impact of broad money global liquidity and M4 annual growth calculated as $\beta_{G L^{\text {broad }, 1}} \alpha_{t-5}^{M 4}+\beta_{G L^{\text {broad }, 2}}\left(1-\alpha_{t-5}^{M 4}\right)$, with $\beta_{G L^{\text {broad }}, 1}=0.17, \beta_{G L^{\text {broad }}, 2}=0$ (imposed), and $\beta_{M 4,1} \alpha_{t-5}^{M 4}+\beta_{M 4,2}\left(1-\alpha_{t-5}^{M 4}\right.$ ), with $\beta_{M 4,1}=0$ (imposed), $\beta_{M 4,2}=0.07, \quad \tau_{1}=7.09 \%, \quad \tau_{2}=10.28 \%$ and $\gamma=5.32$ respectively. These are based on the estimates reported in Table 3 (iii) for the non-linear model that includes annual growth rate of broad money global liquidity and annual growth rate of M4, using M4 growth as the transition variable. 